\title{
A study on genetic aspects of male infertility in North-east Indian population, India
}

\author{
Purnali Nath Barbhuiya ${ }^{1 *}$, Anannya Gogoi², Giasuddin Ahmed ${ }^{3}$, Rita Mahanta ${ }^{4}$ \\ From Beyond the Genome 2012 \\ Boston, MA, USA. 27-29 September 2012
}

\section{Background}

Male infertility refers to the inability of a male to achieve a pregnancy in a fertile female [1]. Genetic factors are an important cause of male infertility. The present study was aimed to determine the role of Y-chromosome microdeletion and mitochondrial DNA (mtDNA) mutations - two major causes of male infertility, with special emphasis on patients of North-east India.

\section{Materials and methods}

A total of 500 infertile male patients attending private infertility clinics of Guwahati, Assam, were selected for the study. Blood and semen samples were collected from the patients. Genomic DNA was isolated from both type of samples and PCR amplification was carried out using specific primer sets. The genes and sequence-tagged site (STS) markers included in the study are: DBY, USP9Y, PRY-2, RBMY, BPY-2, XKRY, CDY-1, CSPG4LY, DAZ, sY84, sY254, sY127, SY145, sY152 and sY153. All genes and STS were amplified efficiently in samples from 100 fertile men tested, but failed to be amplified in samples from fertile women. In order to study the role of mtDNA in sperm motility, semen DNA from 50 patients including 10 Asthenospermic, 20 Asthenoteratozoospermic and 20 oligoasthenoteratozoospermic patients and 20 fertile men were studied using specific primers for four mitochondrial genes, namely ND2, ND4, ATPase6 and ATPase8 followed by DNA sequencing.

\section{Results}

Among the 500 patients included in this study, 130 (26\%) were azoospermic, 185 (37\%) were oligozoospermic and 185 (37\%) were asthenozoospermic. Analysis of PCR amplified products showed that the frequency of $\mathrm{Yq}$ microdeletion in semen samples was $20.8 \%$ (104/500) but $18.6 \%(93 / 500)$ in blood samples, both of which lies in the range ( $0 \%-55 \%)$ as stated by Kihaile et.al [2]. In blood samples frequency of Yq microdeletion was as followed: AZFa 4\% (20/500), AZFb 5.6\% (28/500), AZFc $5.8 \%(29 / 500)$ and AZFd 14.6\% (73/500). Similarly, in

Table $1 \mathrm{mtDNA}$ mutations found in infertile patients

\begin{tabular}{|c|c|c|c|c|}
\hline Type of Infertility & Gene & At nucleotide position & At amino acid position & Nature of mutation \\
\hline Asthenozoospermia & ND2 & T4823C & V118V & Silent \\
\hline Asthenozoospermia & ND2 & T4993C & L175F & Novel \\
\hline Asthenoteratozoospermia & ND2 & C4730T & Т87Т & Silent \\
\hline Asthenoteratozoospermia & ND2 & T5250G & L261V & Novel \\
\hline Asthenoteratozoospermia & ATPase8 & G8557C & L64F & Novel \\
\hline Oligoasthenoteratozoospermia & ATPase6 & T8614G & L30V & Novel \\
\hline Oligoasthenoteratozoospermia & ATPase6 & A8925G & T133T & Silent \\
\hline Oligoasthenoteratozoospermia & ATPase6 & G9064A & A180T & Novel \\
\hline Oligoasthenoteratozoospermia & ND4 & A10978G & L73L & Silent \\
\hline
\end{tabular}

'DBT-Sponsored Institutional Biotech Hubs, Cotton College, Guwahati,

Assam-781001, India

Full list of author information is available at the end of the article 
semen samples frequency of Yq microdeletion was as followed: AZFa 6.4\% (32/500), AZFb 6.6\% (33/500), AZFc $7.6 \%(38 / 500)$ and AZFd 18.4\% (92/500). For mtDNA mutation study the mutations that were present in both fertile and infertile samples, were A4769G (M100M) (Silent) in ND2, A8701G (T59A) (Novel) and A8860G (T112A) (Novel) in ATPase6 gene. The mtDNA mutations which were found only in infertile patient group were given in Table 1.

\section{Conclusions}

The study reveals that the frequency of Yq microdeletion is higher in semen samples than blood samples, possibly because most of the genes studied are testis-specific in nature. This is in accordance with the previous studies $[3,4]$. In both types of samples AZFd regions has highest frequency of Yq microdeletion. The mtDNA mutations common in fertile and infertile patients have also been reported by other Indian researchers [5], but doubted to play any role in infertily [6]. The mutation G9064A in ATPase6 has also been reported to play a role in female infertility [7]. Beside these, the other mtDNA mutations observed in the present study have not been reported previously.

\section{Acknowledgements}

This work was supported by DST Grant under the research project to Dr. Rita Mahanta and also DST grant under Women Scientist-A (WOS-A) scheme to PNBC. Authors are also thankful to the doctors and technicians of the infertility clinics from where the samples have been collected for their support.

\section{Author details}

'DBT-Sponsored Institutional Biotech Hubs, Cotton College, Guwahati, Assam-781001, India. 2. 3Department of Biotechnology, Gauhati University, Guwahati, Assam-781014, India. ${ }^{4}$ Department of Zoology, Cotton College, Guwahati, Assam-781001, India.

Published: 1 October 2012

\section{References}

1. Nowier SR, El-sheikh MM, Abdel Rasool HA, Ismail S: Prevalence of $Y$ chromosome microdeletion in males with azoospermia and severe oligospermia in Egypt. Res J Med Medical Sci 2009, 4:189-195.

2. Kihaile PE, Yasui A, Shuto Y: Prospective assessment of Y-chromosome microdeletions and reproductive outcomes among infertile couples of Japanese and African origin. J Exp Clin Assist Repro 2005, 2:9.

3. Sakthivel JP, Swaminathan M: Y chromosome microdeletions in sperm DNA of infertile patients from Tamil Nadu, south India. Indian J Urol 2008, 24:480-485.

4. Dada $R$, Kumar $R$, Shamsi MB, et al: Higher frequency of $Y q$ microdeletions in sperm DNA as compared to DNA isolated from blood. Asian J Androl 2007, 9:720-722.

5. Kumar R, Bhat A, Bamezai RN, et al: Necessity of nuclear and mitochondrial genome analysis prior to ART/ICSI. Indian J Biochem Biophys 2007, 44:437-42.

6. Palanichamy MG, Zhang YP: Identifying potential pitfalls in interpreting mitochondrial DNA mutations of male infertility cases. Indian JMed Res 2011, 134:447-451.

7. Venkatesh S, Kumar M, Sharma A, et al: Oxidative stress and ATPase6 mutation is associated with primary ovarian insufficiency. Arch Gynecol Obstet 2010, 282:313-318.
doi:10.1186/1753-6561-6-S6-P31

Cite this article as: Barbhuiya et al:: A study on genetic aspects of male infertility in North-east Indian population, India. BMC Proceedings 20126 (Suppl 6):P31.

\section{Submit your next manuscript to BioMed Central and take full advantage of:}

- Convenient online submission

- Thorough peer review

- No space constraints or color figure charges

- Immediate publication on acceptance

- Inclusion in PubMed, CAS, Scopus and Google Scholar

- Research which is freely available for redistribution 